\title{
Personality and religiosity: The influence of normative personality on Black Sunni Muslims religious attitudes and practice
}

\author{
Halim Naeem, Ph.D. \\ Western Michigan University, 2012
}

Background There is a dearth of literature on Black Sunni Muslims in the field of psychology. More so, there is no literature specifically analyzing the influences upon Black religiosity. The literature has established that personality has significant influence upon religiosity (McCullough, M. E., Tsang, J., \& Brion, S., 2003; Hills, P. R., Francis, L. J., \& Jennings, P., 2006; Farias, M., Claridge, G., \& Lalljee, M., 2005). The literature also says that females are more religious than their male counterparts (Jang, S.J. \& Johnson, B.R. 2005;Ahrold, T.K \& Meston, C.M 2010; Collett, J.L \& Lizardo, O. 2009). The present study analyzed the influence of personality, gender and social class upon religiosity for Black Sunni Muslims.

Methods The following hypothesis was investigated: Personality, gender, and social class will affect religious attitudes and practices. The study was done via the internet. Subjects were recruited via social media and email. Subjects were directed to a link taking them to Survey Monkey. The scales were the following NEO-FFI (personality), Barrett Simplified Measure of Social Status (social class), demographic form (gender), Muslim Attitudes Towards Religion Scale (religious attitudes), Religiosity of Islam Scale (religious practice), Religious Close-Mindedness Scale \& Religious Rigidity Scale (Purcell, 1984) (religious attitudes).

Results Participants consisted of 263 Black American Muslims from various Masajid (Mosques) in America. The participants were $72 \%$ female and $28 \%$ being male. The ages ranged from 18 years to 70 years and above. A canonical 
regression analysis using SPSS revealed that personality, gender and social class had significant influence upon religiosity for Black Sunni Muslims. Approximately $30.2 \%$ of the variance in religiosity is explained by personality, gender and social class. Given the results, the hypothesis is confirmed that personality, gender and social class have a significant influence on religiosity.

Conclusion This study showed that there are influences that come from the individual (personality, gender, and social class) which effect religiosity in the Black Muslim community. Approximately $30.2 \%$ of the variance in religiosity was explained by the above variables. This shows that when Black Muslims are practicing Islam, they are not only manifesting a religion through religiosity, but they are manifesting their own personal selves along the issues and strengths within. 